\title{
Sedimentological characters of the mangrove ecosystem of Kali estuary, Karwar, west coast of India
}

\author{
V. Kumar. B ${ }^{1}$ Roopa S.V ${ }^{2}$ K. Gangadhar ${ }^{*}$
}

1- Department of studies in Zoology, Government Arts \&Science College, Karwar- 581303, India

2- Department of Studies and Research in Marine Biology, Karnataka University P.G Centre, Kodibag, Karwar-581303, India

* Corresponding author e-mail: bagalwad@rediffmail.com

\begin{abstract}
Estuarine mangroves give natural support to the protection of the riverbanks, due to their accumulative nature. To study this effect, it is necessary to measure sedimentation rates under estuarine mangroves. Sediment plays an important role in the storage and release of nutrient into the water column, the mineralization of organic carbon deposits by various kinds of microbes. In association with other parameters, the sediment is responsible for the variations in densities of majority of benthic organisms. Regular monthly collections of bottom water and sediment were made for a period thirteen months from January 2008 and January 2009 at five different study sites using the motorized outrigger canoe. The present investigation encompassed collection of data pertaining to various aspects of sedimentology. Sediment temperature varied from $25.10^{\circ} \mathrm{c}$ to $30.45^{\circ} \mathrm{c}$. The $\mathrm{pH}$ ranged between 6.18 to 8.30. Organic carbon Varied between 2.06 to $29.45 \%$, moisture content varied from $20.10 \%$ to 41.88 . Values of interstitial water content is varied between $1.60 \%$ to $30.95 \%$. Wide variation in the percentage composition of sand $(28.45 \%$ to $80.10 \%)$, silt $(12.78 \%$ to $54.28 \%)$, and clay (3.66\% to $33.63 \%)$ was observed.
\end{abstract}

Keywords: Sedimetology , Ecosystem, Mangrove, Kali river, Karwar.

\section{Introduction}

Mangroves, a group of salt-tolerant shrubs and trees, constitute a valuable coastal resource for many tropical and subtropical countries. Their strategic locations at the land-sea interface as well as inherent productivities are highly interactive with the surrounding environments. The mangrove ecosystem not only holds and stabilizes sedimentary deposits from erosion, but acts as a buffer between transitional, near shore, and lagoon or estuarine environments with respect to their influence on freshwater discharge, salinity regime, and the adjacent aquatic system. However, mangroves 
Sustainability, Agri, Food and Environmental Research 1(1): 29-39; 2013

ISSN: 0719-3726

themselves influence the hydrodynamic regime through their physical configuration and thus exert direct effects on the sediment flux. Hence, an attempt has been made in this investigation to understand the textural characteristics of the sediments of Kali estuary and creek to have proper insight into the particle size distribution. Energy conditions and transportational pattern of this sediment has been studied as a starting point to elucidate the environmental quality of the basin, since there is no systematic and detailed textural studies available in this region. Estuaries form a transition zone between river environments and ocean environments and are subject to both marine influences, such as tides, waves, and the influx of saline water; and riverine influences, such as flows of fresh water and sediment. The inflow of both seawater and freshwater provide high levels of nutrients in both the water column and sediment, making estuaries among the most productive natural habitats in the world.

\section{Materials \& Methods}

Mavinahole creek which is situated at northern part of the Kali estuary, where the hydrographical parameters are highly influenced by the influx of river water and inshore waters (Figure 1). Station 2 is fixed in the backwaters of Kanasgeri, which is about $3.25 \mathrm{~km}$ away from the estuary point located on the northern bank of River Kali and has a vast and luxuriant growth of mangrove floral stretch. Third study station is also located in the mangrove habitat Sunkeri which is about $5.75 \mathrm{~km}$ from the estuary point and located at the southern bank of the river is covered with rich mangrove floral stretch with maximum mangrove species. Station 4 is situated around $9 \mathrm{~km}$ from the Kali estuary and is located in the Kadwad area. This study point located in the mangrove habitat of the river and this area is also known for good fishery throughout the year. Station 5 is located in the Kinnar which is around $12.5 \mathrm{~km}$ from the estuarine point and is mostly fresh water biotope with more number of freshwater fin fish species.

Regular monthly collections of bottom water, sediment and benthos were made for a period thirteen months from January 2008 and January 2009 at five different study sites using the motorized outrigger canoe. The sediment samples were collected with the help of a Petersen grab having mouth biting an area of $2651.7 \mathrm{~cm}^{2}$ and depth of $15 \mathrm{~cm}$. A plastic core or quadrate was used to take sample from the central part of the grab sample. After collection of the sediment samples, immediately sediment temperature, $\mathrm{pH}$, moisture content, Interstitial water \& organic carbon were observed. And was immediately brought to the laboratory for further analyses like sediment texture. 


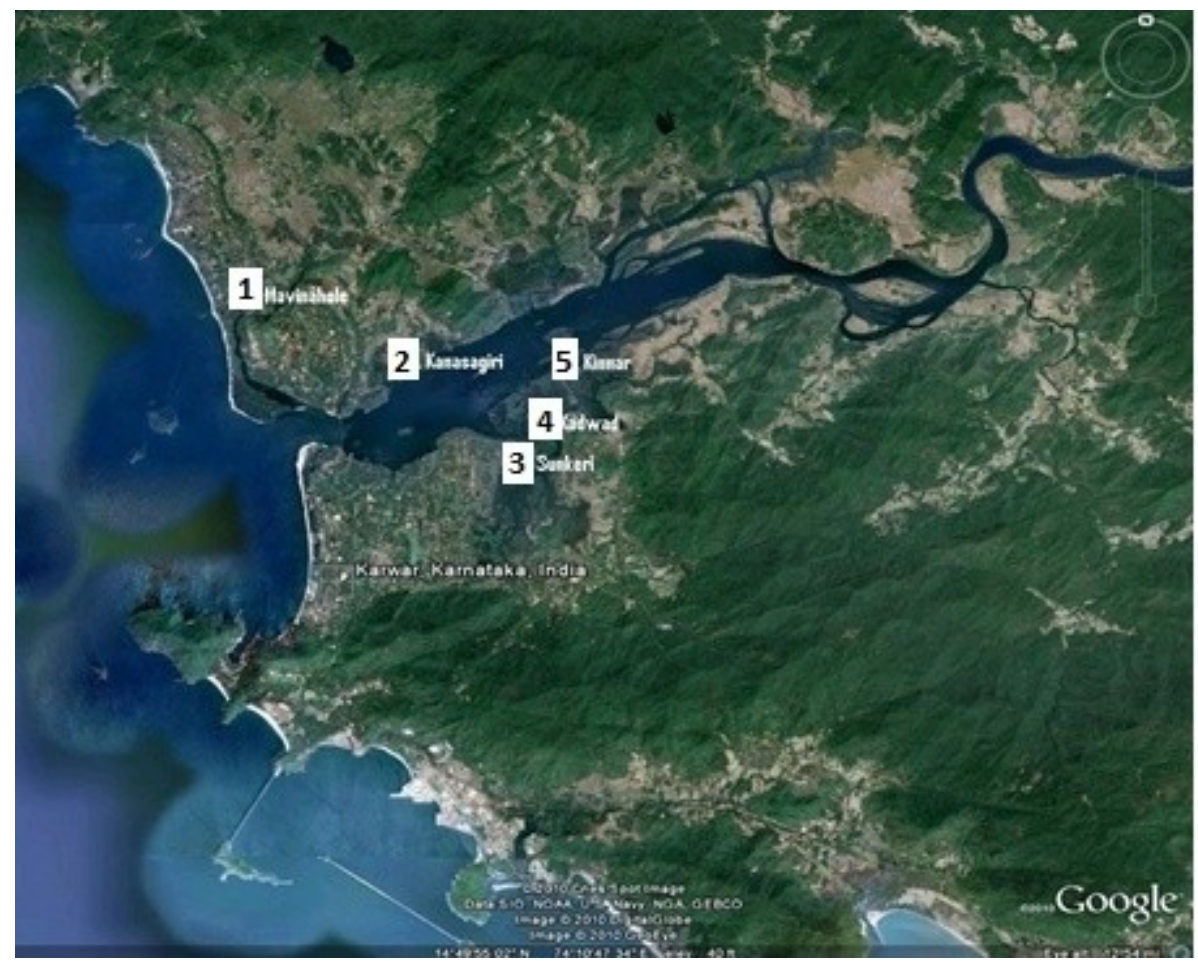

Figure 1: Map showing the location of the study stations in the mangrove: 1: Mavinahole; 2: Kanasageri; 3: Sunkeri; 4: Kadwad; 5:Kinnar

Sediment texture: sediment grain size analysis was carried out with the help of sieves. Silt and clay fractions were determined by pipette analysis as described by Holme \& McIntyre (1971). Later, the results were plotted on triangular diagrams (Eltringham, 1971; Holme \& McIntyre 1971; Parsons et al., 1977) and the sediment texture was determined.

The depth could not be considered as an additional bearing during the relocation of the stations as it varied around the year owing to land run off and other natural processes. Hence, the standard deviation of depth is calculated the values are given in Table 1. The standard deviation is determined as follows, 


$$
\text { Standard deviation }=v \underline{\underline{\Sigma}(m-M)^{2}}
$$

$\mathrm{n}$

Where, $\mathrm{m}=$ depth in different months

$$
\begin{aligned}
& M=\text { mean depth } \\
& n=\text { number of sampling }
\end{aligned}
$$

\section{Results and Discussion}

Sediment temperature did not vary much among the five study stations and all stations showed more or less similar pattern of distribution during the study period (Fig. 2). The yearly mean varied between 27.70 (Stn. 4) and 28.69 (station 1) (tab 1). In all study stations, maximum temperature recorded during pre monsoon and minimum during southwest monsoon season. Variation in values at study sites could be due to recording at different timings.

Fig. 3 explains the variation and trend in the hydrogen ion concentration $(\mathrm{pH})$ parameter at all five-study stations during the present study period. Maximum values were recorded at station 2 during April to July whereas other stations showed more or less similar trend and minimum values were noticed at station 3. Yearly mean values with SD in parenthesis, at study station 1-5 are of $7.69( \pm 0.31)$, $7.75( \pm 0.29), 6.67( \pm 0.39), 6.78( \pm 0.30)$ and $6.76( \pm 0.26)$ respectively (Table 1$)$.

Among five stations, maximum values of organic carbon were noticed at station 1 throughout the study period whereas minimum values noticed at station 4 whereas at stations $2^{\text {nd }}$ and $5^{\text {th }}$ comparatively higher organic carbon content was recorded in the sediment (Fig. 4). Yearly mean of all the stations recorded at study stations 1 to 5 are $2.82( \pm 0.57), 2.65( \pm 0.40), 2.46( \pm 0.18), 2.33( \pm 0.25)$ and $2.56( \pm 0.63)$ respectively (Table 1$)$. The high percentages of organic carbon may be due to relatively denser benthic populations present in the saline waters. During the pre and post monsoon months the lower amounts of organic carbon present in the sediment may be due to the fresh water influx. Similar findings were recorded in other parts of west coast of India by several workers (Fernando, 1981; Kidwai et al., 1972., Paropakari, 1979)

Among the five study stations, the lowest values of moisture content were recorded at station 5 and highest at station 3 respectively (Fig. 4). In all these study stations, maximum moisture content values were recorded during southwest monsoon and post monsoon seasons respectively. Yearly mean 
Sustainability, Agri, Food and Environmental Research 1(1): 29-39; 2013

ISSN: 0719-3726

of station 1 to 5 are of $28.99( \pm 5.25), 30.23( \pm 4.28), 33.53( \pm 6.26), 31.18( \pm 4.99)$ and $27.78 \%( \pm 5.69)$ (Table 1).

Among the five study stations, the lowest values of interstitial water content was recorded at station 3 and highest at station 1 respectively (Fig. 5). In all these study stations, maximum interstitial water content values were recorded during southwest monsoon and in post monsoon seasons respectively. Yearly mean of station 1 to 5 are of $28.20( \pm 1.12), 27.96( \pm 0.51), 27.03( \pm 0.99), 27.55$ $( \pm 0.90)$ and $28.63 \%( \pm 0.46)$ (Table 1$)$.

Table 1: Monthly variations in different Sedimentological parameters at Station 1 - Mavinahole creek

\begin{tabular}{|c|c|c|c|c|c|c|c|c|}
\hline Months & $\begin{array}{c}\text { Sediment } \\
\text { Temperature }\left({ }^{\circ} \mathrm{C}\right)\end{array}$ & $\mathrm{pH}$ & $\begin{array}{r}\text { Organic } \\
\text { Carbon (\%) }\end{array}$ & $\begin{array}{c}\text { Moisture } \\
\text { (\%) }\end{array}$ & $\begin{array}{l}\text { Int. water } \\
\text { (\%) }\end{array}$ & $\begin{array}{l}\text { Sand } \\
(\%)\end{array}$ & $\begin{array}{l}\text { Silt } \\
\text { (\%) }\end{array}$ & $\begin{array}{l}\text { Clay } \\
(\%)\end{array}$ \\
\hline Jan-08 & 28.80 & $\begin{array}{c}7.4 \\
3\end{array}$ & 3.51 & 24.38 & 29.12 & 65.10 & 18.18 & 16.15 \\
\hline Feb & 28.10 & $\begin{array}{c}7.2 \\
1\end{array}$ & 3.06 & 25.95 & 29.62 & 66.28 & 18.32 & 14.38 \\
\hline Mar & 29.20 & $\begin{array}{c}7.5 \\
0\end{array}$ & 2.26 & 26.13 & 28.34 & 71.18 & 15.40 & 14.28 \\
\hline Apr & 29.30 & $\begin{array}{c}7.6 \\
2\end{array}$ & 3.40 & 24.10 & 30.26 & 64.20 & 20.18 & 16.10 \\
\hline May & 29.75 & $\begin{array}{c}7.9 \\
2\end{array}$ & 3.38 & 24.20 & 28.45 & 59.48 & 23.48 & 18.72 \\
\hline Jun & 28.56 & $\begin{array}{c}8.3 \\
0\end{array}$ & 2.30 & 37.06 & 30.12 & 68.14 & 16.10 & 15.38 \\
\hline Jul & 27.40 & $\begin{array}{c}8.1 \\
0\end{array}$ & 2.27 & 36.80 & 30.63 & 73.10 & 14.18 & 14.13 \\
\hline Aug & 28.00 & $\begin{array}{c}7.9 \\
0\end{array}$ & 2.06 & 37.10 & 30.95 & 74.82 & 13.60 & 11.32 \\
\hline Sept & 28.10 & $\begin{array}{c}7.8 \\
0\end{array}$ & 2.19 & 34.22 & 28.85 & 77.32 & 12.78 & 10.16 \\
\hline Oct & 29.30 & $\begin{array}{c}7.7 \\
2\end{array}$ & 2.68 & 28.48 & 28.13 & 69.10 & 14.18 & 15.18 \\
\hline Nov & 29.40 & $\begin{array}{c}7.6 \\
8\end{array}$ & 2.63 & 27.10 & 26.90 & 68.10 & 16.20 & 16.42 \\
\hline Dec & 28.00 & $\begin{array}{c}7.5 \\
2\end{array}$ & 3.52 & 26.12 & 29.12 & 62.40 & 19.80 & 17.68 \\
\hline Jan-09 & 29.10 & $\begin{array}{c}7.3 \\
0\end{array}$ & 3.41 & 25.24 & 29.15 & 64.82 & 17.64 & 17.10 \\
\hline Mean & 28.69 & $\begin{array}{c}7.6 \\
9\end{array}$ & 2.82 & 28.99 & 29.20 & 68.00 & 16.93 & 15.15 \\
\hline $\mathrm{SD}( \pm)$ & 0.72 & $\begin{array}{c}0.3 \\
1\end{array}$ & 0.57 & 5.25 & 1.12 & 5.09 & 3.06 & 2.39 \\
\hline
\end{tabular}


Sustainability, Agri, Food and Environmental Research 1(1): 29-39; 2013

ISSN: 0719-3726

Among five study stations, station 1 showed comparatively higher values of sand whereas at station 3 lower sand proportions were recorded during the study period (Fig. 6 and 7). Comparatively higher sand content was noticed at all study stations $(50.61-65.0 \%)$ respectively. The yearly mean values of this parameter are of $68.00( \pm 5.09), 66.63 \%( \pm 9.40), 51.40( \pm 13.85), 51.85( \pm 8.02)$ and 53.12 $( \pm 2.73)$ respectively (table 1 ).

Fig. 8., explains monthly variation in silt content in the sediment texture at study stations 1-5 during the present study period. Lowest proportion of silt was noticed at station $1(16.93 \%)$ and highest in station 3 (33.45\%). The yearly mean values of this parameter are of $16.93( \pm 3.06), 25.67 \%( \pm 5.32)$, $33.45( \pm 10.36), 27.10( \pm 5.35)$ and $32.94( \pm 7.58)$ respectively (table 1$)$.

Fig. 9 explains the clay content in the sediment samples ranging from $9.58 \%$ (\#2) to $20.14 \%(\# 4)$ during south west and post monsoon seasons (Table 1). During the present study period, yearly mean values of silt content in the sediment at different study stations were of $15.15 \%( \pm 2.39), 9.58 \%( \pm 3.60)$, $17.65 \%( \pm 7.07), 20.14 \%( \pm 8.06)$ and $14.15 \%( \pm 5.99)$ respectively.

The high percentages of organic carbon may be due to relatively denser benthic populations present in the saline waters. During the pre and post monsoon months the lower amounts of organic carbon present in the sediment may be due to the fresh water influx. Similar findings were recorded in other parts of west coast of India by several workers (Fernando, 1981; Kidwai et al., 1972, Murthy et al., 1969;. The sediment texture also plays a very important role in contributing the organic carbon to the benthic realm. The finer grain sizes are believed to hold good amount of these materials within it. In general, according to Sanders (1956), all the clay mineral except Kaolin bind the organic carbon and the area with the high percentage of clay is capable of having high proportion of organic carbon during the different seasons. Similar findings were also noticed in the present investigation especially in the lower reaches (mangrove area) of the river Kali.

It is a known factor that a whole set of benthic organisms depend directly or indirectly on the nature and texture of bottom sediment in which they live. The organisms, which live wholly within the sediment, belong to the former category and those organisms, which depend on the sediment only for the purpose of support to the latter. The factors like organic carbon, sediment texture etc are the determinant factors for the survival, growth and propagation of the benthic organisms, especially of infauna in an aquatic environment.

Wide variation in the percentage composition of sand, silt and clay was observed over the seasons and stations. Sediment texture being predominantly sandy in nature, the average percentage composition was observed to be about $70 \%$ (post monsoon), $60 \%$ (pre monsoon) and $69 \%$ (southwest 
Sustainability, Agri, Food and Environmental Research 1(1): 29-39; 2013

ISSN: 0719-3726

monsoon). However, few of stations showed less than $45 \%$ in each of the seasons. Silt and clay percentage range from 10-30 percent and 5-40 percent is depending on the season and location of the sites.

Figure 2: Monthly variation in the sediment temperature at study stations 1-5

Figure 3: Monthly variation in the $\mathrm{pH}$ at study stations 1-5 
Figure 4. Monthly variation in the moisture at study stations 1-5

Figure 5. Monthly variation in the interstitial water at study stations 1-5

Figure 6. Monthly variation in the sediment organic carbon at study stations 1-5 
Figure 7. Monthly variation in the sand content at study stations 1-5

Figure 8. Monthly variation in the sediment temperature at study stations 1-5

Figure 9. Monthly variation in the sediment temperature at study stations 1-5

The study of sediment along with the hydrological conditions is equally important and also essential in understanding the principles operative in an ecosystem. Sediment plays an important role in the 
storage and release of nutrients into water column, the mineralization organic bottom deposits by various kinds of microbes also provides a two dimensional substrate to sustain benthic life and not to mention of its importance as bed for the growth of algal pasture in shallow area (Naik et al., 2005). In all soil characters either directly or indirectly reflects the productivity of the system as a whole through parameters such as texture, composition, $\mathrm{pH}$, interstitial water and organic matter. During the monsoon season, the mixing of water in the estuaries leads to flocculation resulting in the deposition of fine grained sediments. This type of deposition takes place within the 15 to $50 \mathrm{~m}$ water depths corresponding to the distance of about $40 \mathrm{~km}$ from the coast (Bhat, 1984). This type of near shore deposition of river discharged sediments is common on shelves also. Other processes that may be operating in the deposition in environment and brings about are distribution of bottom sediments by bottom currents. These currents can be a combination of the tide and or wave generated. It is due to these currents play an important role in the sediment are process in the estuaries and neighbouring water spread area. This finding holds well in the present study areas also. On the shelf of Karnataka three most abundant sediment types are found namely clayey silt, silty-sand and sand. The clayey silt forms a relatively narrow band confined to less that $50 \mathrm{~m}$ water depth and within a distance of 25 to $40 \mathrm{~km}$ from the coast.

Thus it is observed from the various sets of data on sedimentological factors studied during the present investigation that there has been no significant variation between the study stations but seasonally it varies considerably this could be probably due to the impact of southwest monsoon season which is sever on the bottom substratum of the mangrove ecosystems.

\section{References}

Bhat, U.G., 1984. Benthos of Kali Estuary, Karwar.Ph.D. Thesis, Karnatak University, Dharwad, India 340 .

Eltringham, S.K., 1971. Life in mud and sand. The English Universities press Ltd., London, U.K. 218.

Fernando, O.J. and Fernando, 1988.Intertidal sediment characteristics of Vellar estuary.Mahasagar. 21: 245-251.

Ghosh, P.B. and A. Chowdhari, 1989.The nutrient status of the sediments of Hooghly estuary. Mahasagar 22: 37-41.

Holme, N.A. and A.D. McIntyre, 1971. Eds. Methods for the study of marine benthos, IBP Handbook,16,Blackwell scientific publications, Oxford. 334 PP. 
Kidwai, R.M., 1972.Grainsize, distribution and mineralogy of Miramer beach. Journal of Geological Society India, 12: 395-398.

Mahadevan, 1955 .Silt and clays in the continental shelf and their industrial possibilities. Bulletin of National. Institute Sciences of India, 5: 22-27.

Naik, U.G., J.L.Rathod, U.G. Bhat and N.Kusuma,2005. Studies on sediments of Bianga and Karwar Bay, west coast of India. Environment and Ecology, 23: 826-830.

Paropakari, L.A., 1979.Distribution of organic carbon in sediments of North western constinental shelf of India. Indian Journal of Marine Sciences 8: 127-129.

Parsons, T.R., M. Takahashi and B.T. Hargrave, 1977.Biological Oceanographic Processes. Pergamon Press. Oxford, 176-264.

Ramachandran, K.K. and T.K. Malik, 1985.Sedimentological aspects of Allepey mud bank, West coast of India. Indian Journal of Marine Sciences 14: 133-135.

Rhodas, D.C. and D.K. Young, 1971.Animal-sediment relations in Cape Cod Bay, Massachusettes. II.Reworking by Molpadia oolitica (Holothuroidea). Marine Biology 11: 255-261. 